\title{
PENANGGULANGAN KEJAHATAN PEROMPAKAN LAUT DI INDONESIA BERDASARKAN PERSPEKTIF HUKUM PIDANA INTERNASIONAL*
}

\author{
Kurniasanti ${ }^{1}$, Joko Setiyono ${ }^{2}$ \\ Fakultas Hukum, Universitas Diponegoro, Semarang, Indonesia \\ 1email: kurniasantihameed1881@gmail.com" \\ 2 email: jokosetiyono61@yahoo.com
}

\begin{abstract}
The crime of piracy at sea is one of the acts of violence or illegal detention, or any act of destruction committed for personal purposes by the crew of a ship or a passenger of a private ship or aircraft and aimed at the high seas, against other ships or aircraft or against persons or goods that are on board a ship or aircraft somewhere outside the jurisdiction of any country. This article aims to analyze the implementation of the universal jurisdiction of a country in tackling the crime of marine piracy in Indonesia and the preventive measures applied by the government in protecting Indonesian-flagged ships in foreign territorial waters that are prone to armed robbery. This research uses doctrinal legal research. Doctrinal legal research is research on law that is conceptualized and developed on the basis of the doctrine adhered to by the conceptor and / or the developer. Sources of legal information use primary legal materials (regulations and relevant documents) for further qualitative analysis. The approach used is statutory, conceptual, and analysis to help solve the problem formulation. Piracy is a common enemy of the international community which has tremendous consequences for international security. Regarding prosecuting perpetrators of piracy crimes, in this case international law itself has transferred its powers to all countries, namely the application of the principle of universal jurisdiction.
\end{abstract}

Keywords: State Jurisdiction; Laur Piracy; International Criminal.

\begin{abstract}
Abstrak
Kejahatan perompakan di laut merupakan salah satu tindakan kekerasan atau penahanan yang tidak sah, atau setiap tindakan memusnahkan yang dilakukan untuk tujuan pribadi oleh awak kapal atau penumpang dari suatu kapal atau pesawat udara swasta dan ditujukan di laut lepas, terhadap kapal atau pesawat udara lain atau terhadap orang atau barang yang ada di atas kapal atau pesawat udara di suatu tempat di luar yurisdiksi negara manapun. Artikel ini bertujuan untuk menganalisis implementasi yurisdiksi universal suatu negara dalam menanggulangi kejahatan perompakan laut di Indonesia dan upaya pencegahan yang diterapkan oleh pemerintah dalam perlindungan terhadap kapal berbendera Indonesia yang berada di wilayah perairan asing yang rawan kejahatan perampokan bersenjata (armed robbery). Penelitian ini menggunakan penelitian hukum doktrinal. Penelitian hukum doktrinal adalah penelitian-penelitian atas hukum yang dikonsepkan dan dikembangkan atas dasar doktrin yang dianut sang pengkonsep dan/atau sang pengembangnya. Sumber informasi hukum menggunakan bahan hukum primer (peraturan dan dokumen relevan) untuk selanjutnya dilakukan analisis secara kualitatif. Pendekatan yang digunakan adalah perundang-undangan, konseptual, dan analisis dalam membantu pemecahan rumusan masalah. Perompakan merupakan musuh bersama masyarakat internasional yang memiliki akibat yang luar biasa bagi keamanan internasional. Terhadap mengadili pelaku kejahatan perompakan dalam hal ini hukum internasional sendiri sudah menyerahkan kewenangannya kepada semua negara, yaitu diberlakukannya prinsip yurisdiksi universal.
\end{abstract}

Kata Kunci: Yurisdiksi Negara; Perompakan Laut; Pidana Internasional.

\footnotetext{
* Naskah diterima: 29 Juni 2020, direvisi: 18 September 2020, disetujui untuk terbit: 28 September 2020

Doi: $10.3376 /$ jch.v6i1.270
} 


\section{PENDAHULUAN}

Perompakan sampai sekarang masih terjadi pada laut lepas, berlangsung pada lintas-lintas yang strategis diantaranya lintas perdagangan internasional yang disebut sebagai wilayah laut internasional (Utami, Muslimah, \& Kusumo, 2014; Yanti \& Sari, 2017). Ketika kapal-kapal yang melewati lintas tersebut dengan membawa barang-barang atau bendabenda yang berharga, tentu akan menjadi kesempatan bagi perompak untuk melakukan kejahatan berupa pencurian maupun menawan awak kapal supaya memperoleh uang tembusan dari pemilik kapal (Rahman \& Susiatiningsih, 2019; Yustitianingtyas, 2015). Daerah perairan yang cukup berbahaya terjadinya kejahatan perompakan dan perampokan bersenjata (armed robbery) seperti pantai Somalia, Selat Malaka, Lepas Pantai Afrika Tengah, Laut Cina Selatan, dan sebagainya.

Hukum Internasional sendiri membedakan penyebutan penamaan perompakan (piracy) serta perampokan bersenjata (sea/armed robbery). Istilah perompakan (piracy) diartikan sebagai perbuatan melawan hukum yang terjadi di laut lepas dengan cara kekerasan maupun penahanan secara tidak sah yang dibuat untuk kebutuhan individu. Sedangkan, kejahatan yang berlangsung pada wilayah laut disebut sebagai perampokan (sea/armed robbery) (Utami et al., 2014). Upaya dalam menanggulangi kejahatan tersebut berpengaruh dalam kewenangan mengadili (yurisdiksi) yang berlaku.
Kejadian perampokan tersebut pernah terjadi terhadap kapal yang berbendera Indonesia oleh perampok Filipina yakni kelompok Abu Sayyaf yang bermarkas di sekitar kepulauan selatan Filipina merupakan kelompok milisi islam garis keras. Permasalahan ini menimbulkan pertanyaan bagaimana perlindungan yang diberikan pemerintah kepada warga negaranya yang berada pada wilayah negara lain (Vidianditha, Mangku, \& Yuliartini, 2020). Kejadian tersebut sangatlah mengkhawatirkan dan menakutkan bagi awak kapal serta keluarganya terutama dalam keselamatan pelayaran Indonesia, yang tentu para awak kapal perlu perlindungan dan jaminan keselamatan dari pemerintah Indonesia yang sudah termuat di dalam konstitusi Indonesia.

Hukum internasional telah menganggap bahwa perompakan merupakan kejahatan bagi manusia. Adapun buku dengan judul "Pengantar Hukum Pidana Internasional II" yang dikarang oleh Romli Atmasasmita, beliau mengatakan kejahatan internasional sendiri contohnya kejahatan terhadap kemanusiaan, genosida, agresi serta kejahatan perang (Pasal 5 Statuta ICC/ International Criminal Court), dan beberapa kejahatan lain contohnya pembajakan, perompakan, diatas pesawat udara, pemalsuan mata uang, terorisme serta narkotika masuk ke dalam kewenangan mengadili atau yurisdiksi Mahkamah Pidana Internasional (International Criminal Court) (Atmasasmita, 2004). Maka dari itu 
Kurniasanti, Joko Setiyono: Penanggulangan Kejahatan Perompakan Laut di Indonesia...

perompakan masuk ke dalam kejahatan internasional.

Pemberantasan kejahatan perompakan yang merupakan kejahatan internasional berlaku prinsip yurisdiksi universal. Bagi semua negara mempunyai yurisdiksi dalam mengadili pelaku kejahatan internasional tersebut tanpa sama sekali memperhatikan asal atau kebangsaan dari pelaku maupun korban itu sendiri. Pemikiran tersebut memunculkan adanya pandangan bahwa kejahatan tersebut merupakan kejahatan bagi semua umat manusia, serta adanya keinginan bersama dalam membasmi kejahatan perompakan, sehingga dibutuhkan kesepakatan bersama setiap negara di dunia.

Desakan yang dibuat oleh sebuah negara kepada pelaku perompakan dengan bertindak mengatasnamakan seluruh masyarakat internasional. Pada prinsip yurisdiksi universal dalam pasal 100 United Nations Convention on the Law of the Sea 1982 yang dikenal sebagai UNCLOS dikatakan bahwa negara-negara diminta bekerja sama untuk memberantas kejahatan perompakan di laut lepas maupun lokasi yang berkedudukan di luar yurisdiksi suatu negara. Adapun syarat perlu dipenuhi oleh sebuah negara dalam melaksanakan yurisdiksi universalnya dalam mengadili pelaku kejahatan internasional perompakan serta kejahatan internasional lainnya diantaranya negara itu harus mempunyai aturan atau norma dalam hukum positifnya (Haryanto \& Setiyono, 2017).
Mengadili pelaku kejahatan internasional suatu negara sama sekali tidak mempunyai aturan atau ketentuan, maka negara tersebut tidak dapat memakai haknya yang diperoleh dari hukum internasional dalam mengadili pelaku kejahatan internasional tersebut. Tentu akan menjadi masalah dengan memberikan pembebasan tanpa hukuman kepada pelaku perompakan, padahal kejahatan perompakan merupakan musuh bersama masyarakat internasional yang memiliki akibat yang luar biasa bagi keamanan internasional.

Terhadap mengadili pelaku kejahatan perompakan dalam hal ini hukum internasional sendiri sudah menyerahkan kewenangannya kepada semua negara, yaitu diberlakukannya prinsip yurisdiksi universal. Jadi suatu negara tidak bisa menggunakan kewenangan tersebut, tentu hal ini membolehkan kejahatan perompakan berjalan serta mengintimidasi keselamatan perairan navigasi semua negara.

\section{METODE PENELITIAN}

Penelitian ini menggunakan penelitian hukum doktrinal. Sumber informasi hukum menggunakan bahan hukum primer (peraturan dan dokumen relevan) untuk selanjutnya dilakukan analisis secara kualitatif (Disemadi \& Prananingtyas, 2020; Marzuki \& Faridy, 2020). Pendekatan yang digunakan adalah perundang-undangan, konseptual, dan analisis dalam membantu pemecahan rumusan masalah. Sumber data penelitian ini, terdiri dari bahan hukum primer, bahan hukum sekunder untuk dilanjutkan 
dengan menganalisis secara keseluruhan, terhadap peraturan perundang-undangan, literatur, data, dan beberapa dokumen yang terkait, serta bahan hukum tersier untuk menjelaskan dan membantu dalam menganalisis bahan hukum primer maupun sekunder (Kurniawan, Disemadi, \& Purwanti, 2020).

\section{HASIL DAN PEMBAHASAN}

\section{Penerapan Yurisdiksi Universal Suatu Negara Untuk \\ Menanggulangi Kejahatan \\ Perompakan Laut di Indonesia}

Alasan pokok sebuah negara ketika meminta yurisdiksinya yakni berdasarkan kepada alasan wilayah dan kebangsaannya. Ada beberapa prinsip yuridiksi yang berlaku secara hukum internasional seperti prinsip yurisdiksi teritorial, dan prinsip perlindungan, prinsip teritorial subjektif, prinsip teritorial objektif, prinsip nasionalitas aktif, prinsip nasionalitas pasif serta prinsip universal (Pratiwi, 2018).

Membahas kewenangan mengadili (yurisdiksi) negara Indonesia, maka harus dibahas dahulu masalah kedaulatan negara (Pratiwi \& Nugroho, 2017). Definisi dari kedaulatan negara adalah kekuasaan tertinggi yang dimiliki oleh suatu negara dan tidak ada lagi kekuasaan yang lebih tinggi dari itu. Suatu negara mempunyai kedaulatan melambangkan bahwa negara tersebut sudah merdeka, akan tetapi kedaulatan negara tersebut terbatas pada hukum, baik itu hukum nasional ataupun hukum internasional.
Suatu negara mempunyai kedaulatan pada intinya dibedakan atas dua faktor, yakni faktor internal dan eksternal (Nisa \& Disemadi, 2020). Faktor internal artinya negara mempunyai kekuasaan tertinggi dalam mengatur semua yang berkaitan dengan batas wilayahnya dan faktor eksternal adalah suatu negara mempunyai kekuasaan tertinggi dalam melaksanakan hubungan dengan dunia internasional, dan hubungan tersebut mempunyai keterkaitan dengan kebutuhan negara tersebut (Pratiwi \& Nugroho, 2017). Adanya kedaulatan yang dimiliki oleh negara memunculkan yurisdiksi (kewenangan mengadili) dalam mengatur kebutuhan negara tersebut baik masalah internal maupun eksternal. Negara Indonesia adalah salah satu negara yang berdaulat serta mempunyai yurisdiksi dalam menyelesaikan masalah internal dan eksternalnya.

Kata Yurisdiksi berasal dari kata "yurisdictio" (bahasa latin), yaitu "yuris" yang artinya "punya hukum" atau "punya berdasarkan hukum" dan "dictio" berarti "ucapan" atau "sebutan" (Parthiana, 1990), dengan demikian kata yurisdiksi sendiri dimaknai sebagai kekuasaan yang sudah diberikan oleh hukum dapat dijelaskan sebagai hak yang dipunyai oleh negara dalam melaksanakan sesuatu dengan aturan yang berlaku. Hak sebagai kekuasaan dan kewenangan tersebut bukan karena paksaan ataupun kekuatan melainkan harus didasarkan pada hukum.

Buku dengan judul "The Concept of State Jurisdiction in International Space Law" yang dikarang oleh Imre Anthony 
Kurniasanti, Joko Setiyono: Penanggulangan Kejahatan Perompakan Laut di Indonesia...

Csabafi menyatakan definisi dari yurisdiksi negara (Parthiana, 1990): "Suatu negara memiliki yurisdiksi dalam mengatur dan mempengaruhi dengan perbuatan ataupun tindakan baik legislatif, eksekutif atau yudikatif atas hak-hak pribadi maupun harta kekayaan, perilaku serta kejadian yang bukan satusatunya masalah dalam negeri."

Menurut pengertian tersebut bisa diartikan bahwa yurisdiksi suatu negara adalah kewenangan sebuah negara untuk bisa berbuat, menerapkan, mendudukkan ataupun mendesak berlakunya hukum nasional negaranya di luar batas wilayah kedaulatannya. Menurut O'Brien suatu yurisdiksi negara yang berdaulat terbagi atas tiga yaitu pertama, kewenangan suatu negara dalam melahirkan aturan-aturan hukum untuk manusia, benda, kejadian ataupun tindakan di kawasan wilayahnya (Legislative jurisdiction or prescriptive jurisdiction). Kedua, suatu negara memiliki kewenangan dalam mendesak berlakunya aturan-aturan hukum nasionalnya (executive jurisdiction or enforcement jurisdiction) dan ketiga, pengadilan suatu negara mempunyai kewenangan dalam mengadili dan memberikan putusan hukumnya (yudicial jurisdiction) (Sefriani, 2010).

Sebuah negara bisa membentuk aturan-aturan hukum wilayah teritorialnya, sehingga penduduk yang berada di wilayah kekuasaannya dapat mentaati dan melaksanakan ketentuan tersebut. Negara juga bisa mendesak hukum nasionalnya terhadap wilayah yang berada di luar teritorialnya.
Ketentuan tersebut berfungsi pada kejahatan internasional yang telah diakui sebagai kejahatan internasional, dengan demikian semua negara mempunyai kewajiban dalam memberantas kejahatan tersebut. Kemudian, negara dalam mengadili serta memberikan suatu putusan hukum tujuannya untuk memberikan jaminan keamanan dan ketertiban supaya terhindar dari perbuatan melawan hukum yang diperbuat oleh warga negara asing.

Terkait masalah pidana terdapat 5 (lima) prinsip yurisdiksi berlaku pada hukum internasional yang bisa dipakai oleh negara dalam mengklaim adanya judicial jurisdiction (Sefriani, 2010):

a. Prinsip Yurisdiksi Teritorial, maksudnya bagi semua negara mempunyai yurisdiksi dalam mengadili kejahatan internasional yang berada di wilayah teritorialnya. Ini merupakan kedaulatan yang dimiliki oleh negara, prinsip tersebut dapat mengadili warga negaranya dan warga negara asing yang berbuat tindak pidana maupun pelanggaran di teritorialnya. Inilah yang menjadi dasar utama suatu negara dalam mengadili perkara ini (Thontowi \& Iskandar, 2006);

b. Prinsip Nasionalitas Aktif, maksud prinsip ini setiap negara mempunyai yurisdiksi kepada warga negaranya yang berbuat kejahatan di luar negeri, dimana pelakunya mempunyai hubungan kebangsaan dengan negara yang bersangkutan; 
c. Prinsip Nasionalitas Pasif, berdasarkan prinsip ini setiap negara mempunyai yurisdiksi kepada warga negaranya yang telah menjadi korban kejahatan yang diperbuat oleh warga negara asing di luar negeri;

d. Prinsip Universal, berdasarkan prinsip ini setiap negara mempunyai yurisdiksi kepada warga negaranya dalam mengadili pelaku kejahatan internasional dimana pun ia berada dengan tidak melihat kebangsaan dari pelaku ataupun korban. Munculnya pemikiran tersebut karena adanya pandangan bahwa kejahatan tersebut merupakan kejahatan bersama masyarakat internasional dan adanya keinginan bersama dalam membasmi kejahatan tersebut. Oleh sebab itu dibutuhkan kerjasama seluruh negara agar desakan yang diperbuat oleh sebuah negara merupakan atas nama seluruh umat manusia.

e. Prinsip Perlindungan, dalam prinsip tersebut setiap negara mempunyai yurisdiksi kepada warga negara asing yang berbuat kejahatan dengan kategori kejahatan serius yang dapat mengintimidasi kepentingan suatu negara, keamanan, integritas dan kedaulatan serta kebutuhan ekonomi suatu negara. Adapun contoh yurisdiksi perlindungan diantaranya spying, plots to overthrow the government, forging currency, immigration and economic violation.

Perbuatan yang disebut sebagai kejahatan internasional apabila perbuatan itu memenuhi syarat sebagai pelanggaran yang merugikan masyarakat internasional atau "delicto jus gentium", dengan demikian kejahatan tersebut dibutuhkan penyelesaian berdasarkan internasional (Mauna, 2005). Semua negara mempunyai hak dan juga wajib untuk melakukan penangkapan, penahanan dan penuntutan, serta mengadili pelaku kejahatan internasional dimana pun kejahatan itu ia perbuat (Atmasasmita, 2004; Thontowi \& Iskandar, 2006). Suatu perbuatan maupun tindakan yang bisa disebut sebagai kejahatan internasional harus memenuhi persyaratan sebagai perbuatan yang melanggar kepentingan masyarakat internasional sehingga diperlukan suatu penyelesaian secara internasional. Semua negara terhadap pelaku kejahatan internasional mempunyai hak dan kewajiban dalam melakukan penangkapan, penahanan dan penuntutan, serta mengadili dimana pelaku tersebut berada (Utami et al., 2014). Adanya prinsip yurisdiksi universal yang berlaku dalam hukum tujuannya untuk menghilangkan fakta pengampunan (impunity) untuk pelaku kejahatan internasional (Sunarso, 2009).

Pada abad ke-18 oleh masyarakat internasioanl sudah mengetahui dan mengakui kejahatan perompakan sebagai kejahatan internasional (piracy de jure gentium), kategori kejahatan perompakan masuk ke dalam tindak pidana murni yang sudah ditetapkan sebagai kejahatan internasional. Berdasarkan hukum internasional bahwa kejahatan pembajakan masuk sebagai kejahatan bersama masyarakat internasioanl (homo 
homini lupus) (Mauna, 2005). Buku dengan judul "Pengantar Hukum Pidana Internasional II" yang dikarang oleh Romli Atmasasmita mengemukakan bahwa "international crimes adalah kejahatan yang termasuk yurisdiksi ICC, seperti genosida, kejahatan terhadap kemanusiaan, kejahatan perang dan agresi (Pasal 5 Statuta ICC), dan beberapa kejahatan lain seperti pembajakan di laut dan diatas pesawat udara, pemalsuan mata uang, narkotika dan terorisme" (Atmasasmita, 2004).

Mengadili suatu kejahatan internasional, ada terdapat dua asas yang terdapat dalam Hukum Pidana Internasional untuk memutuskan yurisdiksi suatu negara, yaitu asas au dedere au punere dan asas au dedere au judicare. Asas au dedere au punere diartikan pelaku kejahatan internasional bisa dikenakan sanksi pidana yang diberikan suatu negara dimana ia melakukan kejahatan tersebut (locus delicti), yaitu pemisah wilayah suatu dimana negara itu bisa melakukan ekstradisi kepada negara peminta mempunyai yurisdiksi untuk mengadili pelaku tersebut. Asas au dedere au judicare diartikan bahwa setiap negara mempunyai kewajiban untuk melaksanakan kerjasama dengan negara lain dalam melakukan penangkapan, penahanan, penuntutan serta dalam mengadili pelaku kejahatan internasional (Agustina, 2006).

Terdapat karakteristik prinsip yurisdiksi universal, sebagai berikut (Sefriani, 2010): a. Semua negara mempunyai hak dalam melakukan yurisdiksi universal. Kata "setiap negara" memfokus kepada negara yang punya tanggungjawab dalam berpartisipasi langsung untuk melindungi masyarakat internasional dari dampak yang disebabkan oleh kejahatan serius (serious crime), untuk itu negara mempunyai kewajiban untuk mengadili pelakunya. Hal itu dibuktikan dengan adanya rasa tanggungjawab yang ditandai tanpa adanya niat untuk memberikan perlindungan dan rasa aman terhadap pelaku yang berada di wilayah teritorialnya;

b. Semua negara yang berkeinginan melakukan yurisdiksi universal tidak usah memikirkan siapa dan asal negara baik pelaku maupun korban. Dengan demikian tidak dibutuhkan hubungan negara yang akan melakukan yurisdiksi dengan pelaku. Pertimbangan yang dipakai dalam hal ini adalah pelaku berada di wilayahnya atau tidak, negara dapat melakukan yurisdiksi universal apabila tidak berada di wilayahnya; dan

c. Semua negara bisa melakukan atau menerapkan yurisdiksi universal terdapat pelaku kejahatan yang kategori serius atau disebut sebagai kejahatan internasional.

Ciri-ciri di atas bisa disimpulkan bahwa yurisdiksi universal tidak membutuhkan pertautan negara antara korban, pelaku serta tindak pidananya. Penerapan yurisdiksi universal bisa 
dilakukan untuk kejahatan-kejahatan internasional. Status yang diberikan untuk tindak pidana internasional bergantung kepada dua faktor, yaitu (Agustina, 2006): tindakan tersebut dapat mengancam kebutuhan masyarakat internasional (serious crimes of international concern), sehingga semua negara mempunyai kewenangan dalam mengadili kejahatan tersebut, tidak memandang tempat kejadian kejahatan dan kejahatan tersebut adalah kewenangan Pengadilan Pidana Internasional (Haryanto \& Setiyono, 2017; Pratiwi, 2018; Saraswati \& Setiyono, 2017). Sebuah negara bisa melaksanakan yurisdiksi universalnya jika pelakunya tidak berkedudukan di kawasan teritorial negara lain. Pasal 404 Restatement (Third) of the foreign Relations Law of United States menyatakan yurisdiksi universal diterapkan terhadap piracy, perdagangan budak, attack or hijacking of aircraft, genocide, war crimes, dan terrorism (Sefriani, 2010).

Kasus yang pernah terjadi pada bulan Maret 2016 di perairan Tawi-tawi Filipina Selatan, Kelompok Abu Sayyaf melakukan kejahatan perompakan terhadap kapal yang berbendera Indonesia dengan Kapal Tongkan Anand. Yurisdiksi yang berlangsung ketika itu adalah yurisdiksi negara Filipina, motivasi pelaku yaitu uang tebusan, kejadian tersebut mengingatkan kasus perompakan yang berlangsung pada lepas Pantai Somalia terhadap kapal MV. Sinar Kudus, pada kasus tersebut motif pelaku juga masalah ekonomi, namun peristiwa tersebut berlangsung pada laut lepas bukan laut wilayah teritorialnya.

Kejahatan perompakan di wilayah perairan Somalia sekitar 60 mil terhadap kapal MV. Sinar Kudus yang pernah dirompak oleh perompak asal Somalia. Kapal tersebut berlayar dengan tujuan ke Rotterdam, Belanda. Kapal-kapal asing sering melewati kawasan wilayah perairan Somalia karena merupakan jalur perdagangan dunia. Perairan tersebut sangat rawan kejahatan perompakan dan ini sedang berlangsung lama, harusnya kejahatan tersebut sudah dilakukan upaya pencegahan dan ditanggulangi oleh semua negara. Kejadian perompakan yang berlangsung di wilayah perairan Tawirawi Filipina dan perairan wilayah lepas pantai Somalia mempunyai perbedaan yaitu negara Somalia sebagai negara gagal yang tidak adanya pemerintahan yang efektif di kawasan sana, sedangkan negara Filipina mempunyai pemerintahan yang efektif harusnya penanganan pembajakan bisa teratasi.

Kejadian yang pernah berlangsung di perairan Tawi-tawi secara hukum internasional dan lepas pantai Somalia punya perbedaan yurisdiksi, sehingga muncul istilah Piracy dan Sea/armed Roberry. Definisi Piracy dalam Pasal 101 UNCLOS 1982 adalah:

a. Setiap tindakan kekerasan atau penahanan ilegal, atau tindakan penyusutan, yang dilakukan untuk tujuan pribadi oleh kru atau penumpang kapal atau pesawat pribadi dan diarahkan:

1) di laut lepas, terhadap kapal atau pesawat lain, atau terhadap orang atau properti di atas kapal atau pesawat udara tersebut. 
2) terhadap kapal, pesawat terbang, orang atau properti di tempat di luar yurisdiksi negara bagian mana pun;

b. Setiap tindakan partisipasi sukarela dalam pengoperasian kapal atau pesawat terbang dengan sepengetahuan fakta menjadikannya kapal atau pesawat pribadi; dan

c. Setiap tindakan yang menghasut atau dengan sengaja memfasilitasi suatu tindakan yang dijelaskan dalam ayat (a).

Pengertian tersebut adanya maksud bahwa pengelompokan pembajakan (piracy) merupakan semua perbuatan atau semua tindakan pembasmian yang dilaksanakan untuk keinginan individu baik untuk penumpang atau awak kapal maupun pesawat udara swasta dan peristiwa itu berlangsung di laut lepas atau berada di luar wilayah yurisdiksi suatu negara, tentang piracy tersebut sudah diatur dalam Pasal 100 hingga Pasal 107 konvensi melainkan sea/armed robbery (Ariadno, 2007).

Piracy atau perompakan di dalam pasal 101 memfokuskan pada perbuatan yang terjadi di laut lepas yang berada di laur yuridiksi negara tersebut. Pada negara bendera kapal dalam penegakan hukumnya sudah diberikan, dengan pengecualian kejahatan tersebut masuk kategori kejahatan umat manusia (Simanjuntak, 2018), contohnya perompakan dan perdagangan budak setiap negara mempunyai yurisdiksi dalam mengadili kejahatan itu dengan menggunakan prinsip yurisdiksi universal. Pasal 105 menyebutkan bahwa di laut lepas setiap negara bisa dilaksanakan penyitaan serta penangkapan kepada perompak, kemudian pengadilan negara yang sudah melaksanakan penyitaan dan penangkapan tersebut bisa menetapkan sanksi yang akan diberikan. Sebagaimana diketahui dalam Pasal 107 penyitaan karena perompakan hanya bisa dilaksanakan oleh kapal perang atau kapal lain yang secara jelas diberi lambang dan bisa diketahui sebagai kapal dinas pemerintah (publik) dan diberi wewenang untuk melaksanakan penyitaan. Dengan demikian pemberantasan perompakan dapat dilakukan dengan mengadili pelaku berdasarkan hukum nasional dari kapal perang atau kapal publik yang menangkap perompak tersebut (Prabowo, 2018; Utami et al., 2014; Vidianditha et al., 2020).

Perbedaan mendasar antara kapal publik dengan kapal swasta terlepas pada motifnya dan tidak pada kualitas kapalnya. Kapal publik artinya kapal yang dipakai dengan tujuan wisata untuk dinas pemerintah, sedangkan kapal swasta artinya kapal tersebut dipakai untuk tujuan berdagang, pengelompokan kapal tersebut antara lain kapal perang, kapal publik non-militer, kapal organisasi internasional. Kapal perang masuk kategori kapal publik yang mempunyai kewenangan untuk menanggulangi perompakan, kapal tersebut juga mempunyai kewenangan lain seperti penahan dan penangkapan kapal-kapal perompak, serta kapal tersebut mempunyai kewenangan untuk mengadili perompak yang ditangkap tersebut. 
Penerapan yurisdiksi universal terhadap kejahatan perompakan mempunyai maksud bahwa semua negara punya hak dalam menangkap dan menghukum perompak di laut lepas dengan tidak memandang asal negara serta tempat ia melakukan kejahatan itu (Starke, 2010). Yurisdiksi universal berdasarkan pernyataan internasional adalah yurisdiksi pengadilan negara ataupun bisa mengeksplorasi, melakukan penuntutan terhadap orang yang diduga melakukan perbuatan tindak pidana internasional dengan tidak memandang asal negara pelaku, korban ataupun pertautan dengan negara dimana pengadilan itu berada (Sefriani, 2010).

UNCLOS telah memberikan yurisdiksi pada setiap negara untuk mengadili para perompak yang berlangsung di luar wilayah negara manapun (laut lepas), namun sebagian besar negara justru menghindari kewenangan mengadili tersebut dengan alasan tidak adanya hukum yang layak atau tanpa adanya aturan mengenai kejahatan perbuatan yang dilakukan oleh perompak (Gunawan, 2012), juga terdapat beberapa faktor lainnya seperti biaya yang tinggi, jauhnya lokasi yang mengharuskan membawa barang bukti ke pengadilan tersebut, kesulitan menghadirkan saksi, dan kesulitan dalam bahasa.

Berdasarkan teori hubungan hukum internasional dan hukum nasional ada dua aliran mengenai keberlakuan hukum internasional, yakni aliran monisme dan aliran dualisme. Aliran monisme memandang bahwa hukum nasional dan hukum internasional merupakan dua bagian dari satu kesatuan yang lebih besar yaitu hukum yang mengatur kehidupan manusia. Akibat dari pandangan ini, antara hukum internasional dan hukum nasional ada hubungan hierarki, sehingga aliran ini terbagi menjadi aliran monisme primat hukum internasional dan aliran monisme primat hukum nasional (Atmasasmita, 2004). Aliran dualisme memandang bahwa hukum internasional dan hukum nasional merupakan dua hukum yang berbeda dan berdiri sendiri satu dengan lainnya (Thontowi \& Iskandar, 2006). Akibatnya untuk menerapkan hukum internasional ke dalam hukum nasional diperlukan transformasi ke dalam hukum nasional.

Berdasarkan teori hubungan hukum internasional dan hukum nasional yang sudah dijelaskan sebelumnya, terdapat perbedaan sikap-sikap negara dalam memberlakukan suatu hukum internasional. Inilah yang menjadi dasar adanya kekosongan hukum, dimana dalam aliran dualisme diperlukan transformasi hukum internasional kedalam hukum nasional, sedangkan tidak semua negara mentransformasikan hukum UNCLOS 1982 ke dalam hukum nasionalnya. Sepatutnya negara-negara tersebut membuat ketentuan hukum nasional mengenai perompakan ini, sebab perompakan sudah diakui menjadi musuh bagi seluruh umat manusia. Hal ini agar tidak ada lagi budaya impunitas pada kasus perompakan laut.

Negara Indonesia sebagai negara yang berdaulat mempunyai hak untuk 
memakai yurisdiksinya karena kejahatan perompakan masuk kategori kejahatan yang sudah dibenarkan oleh masyarakat internasional, dengan demikian prinsip universal berlaku untuk kejahatan tersebut. Ketentuan di dalam pasal 4 Kitab Undang-Undang Hukum Pidana (KUHP) menyatakan bahwa aturan pidana dalam undang-undang yang berkedudukan kepada semua manusia yang berada di luar Indonesia berbuat kejahatan antara lain pembajakan laut sebagaimana diatur dalam Pasal 438, 444 sampai dengan Pasal 446 KUHP dan negara Indonesia mempunyai hak dalam mengadili pelaku kejahatan tersebut, dengan itu Negara Indonesia tidak cukup mengamankan kebutuhan mereka saja, melainkan kebutuhan semua negara.

Mengatur perompakan ke dalam hukum nasional tidak cukup hanya menghilangkan budaya impunitas tersebut. Kenyataannya meskipun sudah ada pengaturan nasionalnya di masingmasing negara hal ini kembali lagi dengan kemauan (political will) dari masingmasing negara itu sendiri (Haryanto \& Setiyono, 2017; Saraswati \& Setiyono, 2017). Saat ini kebanyakan tindakan negara adalah membiarkan pelaku selama perompak tersebut tidak mengganggu kepentingannya. Indonesia memilih tidak mengadili pelaku perompakan Somalia karena mempertimbangkan keselamatan kapal dagang selanjutnya, dimana Indonesia belum mampu untuk melakukan patroli atau pendampingan terhadap kapal dagang yang melintasi perairan rawan perompakan (Prabowo,
2018; Yustitianingtyas, 2015), kekhawatiran mengenai dampak negatif lainnya juga menjadi pertimbangan bagi Indonesia untuk mengadili pelaku perompakan di Indonesia seperti isu yang berkembang mengenai penanganan tersangka di wilayah Indonesia yang bisa saja dipolitisir sehingga memicu ketegangan antar dua negara, persoalan bahasa si tersangka dan pembuktian yang mungkin akan sulit untuk dilakukan pemeriksaan (Pratiwi, 2018; Saraswati \& Setiyono, 2017).

\section{Upaya Pencegahan yang} Diterapkan oleh Pemerintah dalam Perlindungan Kapal Berbendera Indonesia yang Berada di Wilayah Perairan Asing yang Rawan Kejahatan Perompakan Bersenjata

Dua buah kapal milik Indonesia yang dibajak oleh kelompok Abu Sayyaf di perairan Tawi-tawi Filipina mengakibatkan sepuluh warga negara Indonesia disandera. Ketika dibajak kapal tersebut sedang dalam pelayaran dari Sungai Putting, Kalimantan Selatan yang akan menuju Batangas, Filipina Selatan (BCC News Indonesia, 2016). Kejahatan pembajakan tersebut yang mempunyai yurisdiksi mengadili adalah Filipina karena negera dimana kejahatan itu diperbuat. Untuk itu Indonesia sama sekali tidak bisa mengintervensi soal proses penangkapan ataupun mengadili pelaku kejahatan tersebut, yang bisa dilakukan Indonesia adalah melaksanakan hubungan diplomasi ke pemerintah Filipina untuk meyakinkan warga 
negaranya dalam kondisi aman (BCC News Indonesia, 2016).

Sebelum kasus pembajakan di Laut Sulu, Selat Malaka merupakan perairan yang bahaya akan kejahatan pembajakan sehingga untuk menangani hal tersebut pemerintah melaksanakan kerjasama dengan negara Malaysia dan juga Singapura (Pangestu \& Rosyidin, 2018; Utomo \& Soepandi, 2013). Para negara pantai sebenarnya telah bekerjasama sejak awal tahun 1970-an melalui beragam konsultasi antar tiga negara, seperti tercapainya kesepakatan antar tiga negara pantai untuk mengatur dua selat (Malaka dan Singapura) sebagai satu selat di tahun 1971, dan formasi landasan kerjasama penting juga tercipta di tahun 1975 yaitu Tripartite Technical Experts Group (TTEG). Koordiansi ini merupakan bentuk awal yang menunjukkan komitmen Pemerintah dalam mendukung keselamatan pelayaran dan perlindungan kawasan maritim di Selat Malaka dan Selat Singapura serta turut berpartisipasi aktif dalam dunia pelayaran Internasional guna mendukung terwujudnya safe, secure and efficient shipping on clean oceans (Utomo \& Soepandi, 2013).

Berdasarkan hukum laut UNCLOS 1982, ketiga negara pantai berperan aktif dalam menegosiasi bentuk-bentuk kerjasama keamanan, selain menciptakan TTEG, munculnya inisiatif koordinasi mengenai keamanan navigasi dan kawasan di Selat Malaka berbentuk pertemuan-pertemuan yang menciptakan agreement dan komite-komite baru seperti Co-operative Mechanism yang dilahirkan dari pertemuan penting mengenai keamanan Selat Malaka yang dilaksanakan pada tahun 2005 di Singapura yang di hadir ketiga menteri luar negeri negara pantai. Keragaman bentuk kerjasama perjanjian dan komite ini mempengaruhi kelancaran proses keamanan dan pelaksanaannya untuk menciptakan selat yang bebas pelanggar hukum dan kriminal lainnya (Pangestu \& Rosyidin, 2018; Prabowo, 2018).

Tripartite Technical Experts Group (TTEG) mulanya di bentuk melalui Joint Statement antara tiga negara pantai secara formal pada tahun 1977 melalui penandatanganan perjanjian keamanan navigasi (Pangestu \& Rosyidin, 2018; Prabowo, 2018). TTEG terdiri dari para ahli administrasi kemaritiman yang berasal dari ketiga negara pantai Indonesia, Malaysia, dan Singapura, yang bertemu setiap tahunnya untuk mendiskusikan dan berkolaborasi membahas isu-isu dengan tujuan memajukan keamanan navigasi dan proteksi kawasan maritim, juga masalah trafik lainnya yang terjadi di Selat malaka. Co-operative Mechanism adalah sebuah mekanisme kerjasama yang diciptakan bagi para negara pantai dan pengguna selat dalam tujuan untuk memperkuat keamanan kejahatan, navigasi, dan perlindungan kawasan di Selat Malaka (Suproboningrum, 2018). Mekanisme kerjasama ini adalah satusatunya cara untuk para negara pantai yang bertanggung jawab bagi keamanan selat bekerjasama dengan para pemegang saham dan para pengusaha industri 
perkapalan lainnya. Kerangka kerja ini menjadi jalan untuk para pembisnis yang terlibat di Selat Malaka untuk membantu keamanan selat, karena "kepentingan" mereka di selat juga cukup besar, kekhawatiran akan meningkatnya kriminalitas di selat menjadi perhatian utama mekanisme kerjasama ini (Suproboningrum, 2018; Utomo \& Soepandi, 2013). Walau tanggung jawab keamanan selat dibebani tiga negara pantai, mekanisme ini membuka jalan untuk para user state atau nonuser state meskipun bantuan yang mereka berikan terbatas pada pendanaan, pengadaan teknologi, dan sebagainya, proses operasional keamanan masih merupakan peran aktif Indonesia, Malaysia, dan Singapura (Prabowo, 2018).

Sebagai respon dari pertumbuhan aksi kriminalitas di Selat Malaka, Indonesia, Malaysia, dan Singapura mengarahkan upaya kerjasama untuk memberantas isu kejahatan dengan operasi MALSINDO. Sebuah operasi gabungan tiga negara yang melibatkan koordinasi patroli kelautan bagi setiap negara pantai. Awal kolaborasi 17 kapal angkatan laut dari tiga negara mengubah pergerakan kriminalitas selat dan sekaligus meningkatkan keamanan secara drastis. Dalam kegiatan patroli terkoordinasi ini, masing-masing Angkatan Laut negara pantai mengikutsertakan sekitar 5-7 kapal perangnya, selain itu disiagakan komunikasi hot line selama 24 jam untuk saling tukar informasi dan laporan, khususnya untuk mempercepat aksi penindakan dari unsur-unsur patroli apabila terjadi gangguan atau ancaman di perairan Selat Malaka (Prabowo, 2018). Kegiatan patroli terkoordinasi ini tidak semata-mata karena adanya laporan IMB, tetapi didorong oleh rasa tanggung jawab tiga negara pantai sebagai bagian negara uang berdaulat untuk mewujudkan stabilitas keamanan di Selat Malaka, dengan adanya hot line 24 jam dapat mempermudah angkatan laut tiga negara pantai Selat Malaka dapat saling tukar informasi dan juga mencegah adanya salah komunikasi yang berakibat fatal (Pangestu \& Rosyidin, 2018; Suproboningrum, 2018).

Berkaca pada kejadian yang kapal Kargo Maesrsk Alabama, kapal tersebut berbendera Amerika Serikat kemudian di rompak oleh perompak asal Somalia di Teluk Aden. Kapal tersebut membawa makanan pesanan Organisasi Pangan PBB. Kapten Kargo Maersk Alabama yakni Richard Philips yang ditahan oleh perompak Somalia. Jika kapal dibajak sesuai dengan mekanisme keamanan kapal maka para awak kapal harus mengarah ke lokasi aman yang dapat diketahui oleh kaptennya beserta awaknya (DW.com, 2009). Ketika itu awak kapal juga meyakinkan bahwa kapal kargo mesinnya tidak dapat digunakan. Kapten Philip juga mengacaukan sinyal komunikasi. Dampaknya, kapal tersebut tidak bisa terlacak oleh para perompak yang ketika itu menunggu kapal induk maupun di pantai dengan begitu awak kapal Maersk Alabama selamat dari 
kawanan perompak kecuali sang kapten yang tidak sempat masuk ke ruang aman tersebut (DW.com, 2009).

Paban V Srenal Kolonel Laut Bapak Taufiq Arif, mengungkapkan kapal Indonesia sudah dilengkapi ruang aman untuk tempat persembunyian awak kapal dalam keadaan bahaya sebagaimana milik kapal Maersk Alabama, dan water canon untuk menghalau kapal perompak yang biasanya menggunakan kapal-kapal kecil, karena Hal tersebut sudah menjadi prosedur internasional yang harus ditaati sehingga dapat memenuhi standar internasional dengan adanya radar dan tombol darurat yang bisa dipakai dalam keadaan darurat yang telah cukup untuk melindungi kapal dari kejahatan perompakan, jika tombol darurat disentuh makan akan menyampaikan ke markas militer terdekat bahwa sudah terjadi kejahatan perompakan pada wilayah tersebut (Pratiwi \& Nugroho, 2017). Dengan adanya Western Quick Response sudah teruji bahwa selat malaka sudah aman dari kejahatan perompakan. Negara Indonesia memberikan masukan untuk kapal-kapal agar memenuhi syarat komunikasi maupun arsip yang telah merupakan standard internasional. Pada intinya dengan mematuhi SOP tersebut telah memadai untuk melindungi kapal dari kejahatan perompakan (Pratiwi \& Nugroho, 2017).

Upaya tersebut dilaksanakan supaya pemerintah bisa mempererat hubungan kerjasama regional dengan ketiga Negara yaitu Malaysia, Filipina dan Indonesia. Pengamanan dilakukan di wilayah perairan sekitar oleh Malaysia dan Filipina (Lestari, 2016). Untuk menangani masalah penyanderaan dan perompakan kepada kapal yang berbendera Indonesia harus dibutuhkan kerjasama dengan Negara lain antara Indonesia dengan Filipina. Kerjasama yang dilakukan baik langsung maupun tidak langsung berpengaruh pada pemberantasan kejahatan perompakan yang terjadi antara Filipina dan Indonesia adalah patrol terkoordinasi (Patkor Philindo) yang dilakukan oleh Tentara Nasional Indonesia Angkatan Laut (TNI AL) dan Republic Philipine Navy/RPN di wilayah perairan perbatasan laut kedua negara itu dengan tujuan dalam melindungi batas laut kedua Negara tersebut (Lestari, 2016).

Secara sementara Patkor dilakukan dan dalam sekali setahun dengan lama waktu sekitar 20 hari dan belum pernah mempunyai SOP untuk mempedomani dalam melakukan Patkor di lapangan. Hal yang menjadi dasar di sini adalah Patkor adalah Undang-Undang Nomor 20 Tahun 2007 Tentang Pengesahan Persetujuan antara pemerintah Republik Indonesai (Indonesia) dan Pemerintah Republik Filipina tentang kegiatan kerjasama dibidang pertahanan dan keamanan. Adanya Patkor antara Malaysia, Filipina dan Indonesia, dengan demikian tiap Negara tersebut melakukan patrol di wilayah yuridiksinya, agar program ini berhasil dibutukan tambahan kapal perang yang melibatkan penjagaan perairan perbatasan Fliliphina dan Indonesia (Lestari, 2016). Kemudian untuk 
tergapainya ketepatan butuh penambahan dan pengembangan sarana dan prasarana pangkalan dalam mendukung penegakan kedaulatan negara di laut dengan melakukan pertahanan negara dan pangkalan, mempersiapkan kekuatan dalam mempersiapkan perang, mencegah semua intimidasi militer melintasi laut, dan melindungi kestabilan keamanan wilayah (Rahman \& Susiatiningsih, 2019; Rustam, 2017).

Adanya kerjasama ini dapat diterapkannya setiap tahun dalam melindungi serta mempererat hubungan antara kedua Negara. Perairan antara ketiga Negara tersebut yang berada di sekitar perairan kepulauan Sulu masih berbahaya pada intimidasi kejahatan perompakan yang diperbuat oleh kelompok Abu Sayyahf karena ada faktor penghambat, sebagai berikut:

a. Distribusi kekuatan yang melibatkan untuk pembatasan Indonesia dan Filipina tidak didasarkan pada jumlah anggotanya, akan tetapi didasarkan pada distribusi kapal perang (KRI) yang menghadapkan pada panjangnya perairan pembatasan Indonesia dan Filipina (Rustam, 2017);

b. Wilayah aktivitas yang dilakukan dalam Patkor Philindo sekarang ini sekitar $120 \mathrm{Nm}$ (hanya 1/5 dari 600 $\mathrm{Nm}$ panjang periran pembatas kedua Negara) belum bisa menutupi semua perairan pembatasan Indonesia dan Filipina; dan

c. Diperlukan Standard Operating Procedure (SOP) dalam menerapkan di lapangan supaya menjadi pedoman untuk menerapakan Patkor di Wilayah Perairan Pembatasan Indonesia dan Filipina (Fajardin, 2017).

Pada akhirnya dicapai sebuah kesepakatan untuk memulai kerjasama patroli maritim ketiga negara. Kesepakatan tersebut diawali dengan peresmian penggunaan MCC (Maritime Command Control) dan Launching TMP lndomalphi di Tarakan pada 19 Juni 2017. Bentuk kerja sama ini nantinya akan diintegrasikan dengan patroli dan latihan darat menggunakan mekanisme yang sudah dikoordinasikan serta disusun sebelumnya. Kegiatan ini menjadi satu role model yang komprehensif guna memberikan jaminan keamanan bagi pengguna lalu lintas seperti nelayan, transportasi serta eksplorasi kekayaan perairan di kawasan Laut Sulu (Fajardin, 2017).

Pasal 111 UNCLOS 1982 mengatur mengenai Hak pengejaran seketika (Hot Pursuit) yaitu Hak yang di konsep dalam menentukan bahwa kapal yang sudah melakukan pelanggaran ketentuan negara pantai tidak bisa bebas dari sanksi atau hukuman apabila kabur dari pengejaran menuju laut lepas (Jamilah \& Disemadi, 2020). Kejadian ini maksudnya dalam situasi tertentu dapat diartikan bahwa negara pantai bisa memanjangkan yurisdiksinya ke laut lepas dalam melakukan pengejaran serta penahanan dari suatu kapal yang dituduh melakukan pelanggaran hukum. Peraturan mengenai hak pengejaran seketika (hot pursuit) ini 
memang dirancang oleh Liga BangsaBangsa pada saat itu untuk penegakan hukum bagi kejahatan perompakan laut. Dengan adanya Patroli terkoordinasi dan hak pengejaran seketika dari UNCLOS akan mempersempit ruang gerak pelaku perompakan dan perampokan bersenjata ini.

\section{SIMPULAN}

Berdasarkan paparan pembahasan di atas, maka dapat disimpulkan: 1). Terkait penerapan prinsip yurisdiksi universal dalam membasmi kejahatan perompakan di Indonesia yang terdapat di dalam pasal 4 KUHP, persyaratan dalam mengimplementasikan yurisdiksi universal harus kejahatan itu berada di luar wilayah yurisdiksi Negara tersebut, yang mempunyai wewenang dalam melaksanakan penangkapan yaitu cukup kapal perang ataupun kapal publik yang diberikan wewenang soal itu terakhir negara kapal perang atau publik tersebut harus memiliki kewenangan mengadili yang diatur dalam hukum nasionalnya. Negara Indonesia telah mempunyai dasar hukum dalam memakai yurisdiksi universalnya, namun terdapat larangan dimana kapal perang Indonesia tidak bisa berpatroli di kawasan yang rawan akan kejahatan perompakan, hal tersebut berkaitan dengan resource yang ada. Kasus yang menimpa kapal Sinar Kudus Indonesia tidak bisa memakai kewenangan mengadilinya, oleh karena itu Indonesia perlu mempertimbangkan lagi keselamatan awak kapalnya; dan 2). Negara Indonesia telah mempunyai dasar hukum dalam memakai yurisdiksi universalnya, namun terdapat larangan dimana kapal perang Indonesia tidak bisa berpatroli di kawasan yang rawan akan kejahatan perompakan, hal tersebut berkaitan dengan resource yang ada. Kasus yang menimpa kapal Sinar Kudus Indonesia belum bisa memakai kewenangan mengadilinya, dikarenakan Indonesia perlu mempertimbangkan lagi keselamatan awak kapalnya.

Saran dari penelitian ini adalah: 1). Melaksanakan kerjasama dengan negara lain yang mempunyai pangkalan militer di wilayah rawan perompakan sehingga jika Indonesia tidak mampu mengawal kapal dagang yang melewati perairan yang bahaya akan perompakan tersebut, kapal dagang Indonesia tetap terjamin keselamatannya dengan adanya kapal perang atau kapal publik negara asing yang telah menjalin kerjasama dengan Indonesia. Mengingat yang dapat melakukan penangkapan dan penyitaan kapal perompak hanyalah kapal publik seperti diatur dalam Pasal 107 UNCLOS 1982. Tentu ada hubungan kerjasama tersebut secara tidak langsung Indonesia ikut serta dalam pemberantasan perompakan di dunia sebagaimana diamanatkan Pasal 100 UNCLOS 1982 yang menyerahkan yurisdiksi universal atas kejahatan tersebut; dan 2). Meningkatkan kerjasama dengan negaranegara maju dan tidak hanya dengan negara perbatasan untuk mengadakan pelatihan demi menumbuhkan kemampuan patroli bagi yang menjaga pantai (cost-guard), pelatihan bersama, penukaran informasi dan penyerahan 
bantuan teknis dalam bentuk meningkatkan keamanan laut wilayah Indonesia dan perbatasan.

\section{DAFTAR PUSTAKA}

Agustina, S. (2006). Pengantar Hukum Pidana Internasional (Dalam Teori dan Praktek). Padang: UNAND Press.

Ariadno, M. K. (2007). Hukum Internasional. Jakarta: Diadit Media.

Atmasasmita, R. (2004). Pengantar Hukum Pidana Internasional II. Jakarta: Hecca Mitra Utama.

BCC News Indonesia. (2016). Dua kapal Indonesia dibajak di Filipina, 10 WNI disandera. Retrieved from https://www.bbc.com/indonesia/beri ta_indonesia/2016/03/160329_indo nesia_kapal_dibajak_filipina

Disemadi, H. S., \& Prananingtyas, P. (2020). Kebijakan Corporate Social Responsibility (CSR) sebagai Strategi Hukum dalam Pemberdayaan Masyarakat di Indonesia. Wawasan Yuridika, 4(1), $1-16$.

https://doi.org/http://dx.doi.org/10.2 5072/jwy.v4i1.328

DW.com. (2009). Perompak Sandera Kapten Kapal Amerika. Retrieved from

https://www.dw.com/id/perompaksandera-kapten-kapal-amerika/a4166352

Fajardin, M. (2017). Indonesia, Filipina, dan Malaysia Sepakat Bentuk Patroli Maritim. Retrieved from https://nasional.sindonews.com/beri ta/1247767/14/indonesia-filipina- dan-malaysia-sepakat-bentukpatroli-maritim

Gunawan, Y. (2012). Penegakan Hukum Terhadap Pembajakan Di Laut Melalui Yurisdiksi Mahkamah Pidana Internasional. Jurnal Media Hukum, 19(1), 72-86. Retrieved from

https://journal.umy.ac.id/index.php/j $\mathrm{mh} /$ article/view/1978

Haryanto, \& Setiyono, J. (2017). Kebijakan Penenggelaman Kapal Asing Pelaku Illegal Fishing Oleh Pemerintah Indonesia Dalam Persfektif Hukum Pidana Internasional. LAW REFORM, 13(1), 70-85. https://doi.org/10.14710/lr.v13i1.15 952

Jamilah, A., \& Disemadi, H. S. (2020). Penegakan Hukum Illegal Fishing dalam Perspektif UNCLOS 1982. Mulawarman Law Review, 5(1), 29-46.

https://doi.org/doi.org/10.30872/mul rev.v5i1.311

Kurniawan, S., Disemadi, H. S., \& Purwanti, A. (2020). Urgensi Pencegahan Tindak Pidana Curang (Fraud) Dalam Klaim Asuransi. Halu Oleo Law Review, 4(1), 3853.

https://doi.org/10.33561/holrev.v4i1 .10863

Lestari, S. (2016). RI, Filipina dan Malaysia sepakat cegah perompakan. Retrieved from https://www.bbc.com/indonesia/beri ta_indonesia/2016/08/160802_indo nesia_pertemuan_menhan 
Marzuki, I., \& Faridy. (2020). Relevansi Hukum Dan Hak Asasi Manusia Dengan Agenda Reformasi: Dimensi Nasional Dan Internasional. Jurnal Cendikia Hukum, 5(2), 350-359. https://doi.org/doi.org/10.33760/jch. v5i2.242

Mauna, B. (2005). Hukum Internasional. Bandung: Alumni.

Nisa, C. U., \& Disemadi, H. S. (2020). Yurisdiksi Kriminal Terhadap Black Flight Di Ruang Udara Wilayah Indonesia. Sasi, 26(3), 365-379. https://doi.org/10.47268/sasi.v26i3. 289

Pangestu, M. R., \& Rosyidin, M. (2018). Ketidakefektifan Malacca Strait Patrol dalam Mengatasi Pembajakan dan Perompakan di Selat Malaka dan Singapura. Journal of International Relations, 5(1), 967978. Retrieved from https://ejournal3.undip.ac.id/index.p hp/jihi/article/view/22696

Parthiana, I. W. (1990). Pengantar Hukum Internasional. Bandung: Mandar Maju.

Prabowo, E. B. (2018). Penindakan Terhadap Perompakan Di Selat Malaka Oleh Tentara Nasional Indonesia Angkatan Laut. Perspektif Hukum, 14(1), 18-32. https://doi.org/doi.org/10.30649/phj. v14i1.29

Pratiwi, D. K. (2018). Implementasi Prinsip Yurisdiksi Universal Mengenai Pemberantasan Kejahatan Perompakan Laut Di Indonesia. Supremasi Jurnal Hukum, 1(2), 5566. https://doi.org/doi.org/10.36441/huk um.v2i1.30

Pratiwi, D. K., \& Nugroho, W. (2017). Implementasi Yurisdiksi Negara Indonesia dalam Pemberantasan Perompakan dan Perampokan Laut Berdasarkan Hukum Internasional. Era Hukum - Jurnal Ilmiah Ilmu Hukum, 15(2), 1-20. https://doi.org/doi.org/10.24912/era \%20hukum.v15i2.1070

Rahman, A. F. N., \& Susiatiningsih, R. H. (2019). Memberantas Kejahatan Transnasional di Jalur Segitiga Asia Tenggara, Wilayah Perairan Laut Sulu. Journal of International Relations, 5(4), 789-796. Retrieved from

https://ejournal3.undip.ac.id/index.p hp/jihi/article/view/25086

Rustam, I. (2017). Kebijakan Keamanan Maritim di Perbatasan Indonesia: Kasus Kejahatan di Laut Sulawesi Laut Sulu. Jurnal Penelitian Politik, 14(2), 161-177. https://doi.org/doi.org/10.14203/jpp. v14i2.717

Saraswati, D. A., \& Setiyono, J. (2017). Yurisdiksi Kriminal Negara Dalam Penenggelaman Kapal Pelaku Tindak Pidana Illegal Fishing Di Perairan Indonesia. LAW REFORM, 13(2), 180-188. https://doi.org/10.14710/lr.v13i2.16 154

Sefriani. (2010). Hukum Internasional. Jakarta: Rajawali Pers.

Simanjuntak, M. (2018). TNI Angkatan Laut Sebagai Penegak Hukum Dan Sekaligus Penyidik Tindak Pidana Di Laut. JURNAL ILMIAH 
Kurniasanti, Joko Setiyono: Penanggulangan Kejahatan Perompakan Laut di Indonesia...

HUKUM DIRGANTARA, 8(2), 8090.

https://doi.org/10.35968/jh.v8i2.256

Starke, J. G. (2010). Pengantar Hukum

Internasional 1. Jakarta: Sinar Grafika.

Sunarso, S. (2009). Ekstradisi dan Bantuan Timbal Balik Dalam Masalah Pidana. Jakarta: Rineka Cipta.

Suproboningrum, L. (2018). Peran Diplomasi Maritim Dalam Keberhasilan Patroli Terkoordinasi Indonesia-Malaysia-Singapura Untuk Menekan Angka Pembajakan Dan Perompakan Laut Di Selat Malaka. Jurnal Hubungan Internasional, 11(1), 19-38. https://doi.org/doi.org/10.20473/jhi. v11i1.4836

Thontowi, J., \& Iskandar, P. (2006). Hukum Internasional Kontemporer. Retrieved from Refika Aditama

Utami, A. D., Muslimah, S., \& Kusumo, A. T. S. (2014). Yurisdiksi Internasional Penanggulangan Perompakan Di Laut Lepas. Yustisia Jurnal Hukum, 3(1), 97-104. https://doi.org/10.20961/yustisia.v3i 1.10130

Utomo, G. W. S., \& Soepandi, S. (2013). Penerapan Hukum Terhadap
Pembajakan Dan Perompakan Di Selat Malaka. Perspektif Hukum, 13(1), 8-14. https://doi.org/doi.org/10.30649/phj. v13i1.48

Vidianditha, K. R., Mangku, D. G. S., \& Yuliartini, N. P. R. (2020). Perlindungan Hukum Yang Diberikan Oleh Indonesia Kepada WNI Sebagai Pelaku Perompakan Kapal (Studi Kasus: Perompakan Kapal Orkim Harmony Milik Malaysia). Jurnal Komunitas Yustisia, 3(1), 260-269. Retrieved from

https://ejournal.undiksha.ac.id/index .php/jatayu/article/view/24025

Yanti, E., \& Sari, D. A. A. (2017). Yurisdiksi Universal Penegakan Hukum Terhadap Pembajakan Kapal Safmarine Asia. Belli Ac Pacis, 3(2), 44-53. Retrieved from https://jurnal.uns.ac.id/belli/article/v iew/27486

Yustitianingtyas, L. (2015). Pengamanan dan Penengakan Hukum di Perairan Indonesia sebagai Konsekuensi Penetapan Alur Laut Kepulauan Indonesia (ALKI). Pandecta: Research Law Journal, 10(2), 143152. https://doi.org/10.15294/pandecta.v 10i2.4949 